\title{
Techniques for Increasing the Biological Efficiency of Paddy Straw Mushroom (Volvariella Volvacea) in Eastern India
}

\author{
M. K. Biswas ${ }^{*}$, Mrinmoy Layak \\ Department of Plant Protection, P.S.B., Visva-Bharati, Sriniketan,W.B.,731236, India \\ *Corresponding Author: mkb.psb@gmail.com
}

Copyright $(2014$ Horizon Research Publishing All rights reserved.

\begin{abstract}
Mushrooms are popular for their delicacy and flavored food value. Among the various mushrooms cultivated in India, paddy straw mushroom (Volvariella spp.) holds a good promise and its cultivation have been introduced as a cottage industry. It has several advantages like requirement of the tropical or sub-tropical climate, fast growth rate, easy cultivation technology and good acceptability at consumers' level. Various methods were employed to enhance the Biological Efficiency of Volvariella volvacea. Cage method of cultivation proved its superiority among all the methods tested and gave highest Biological Efficiency (12.10\%) followed by bed method and spiral method of cultivation. Mixing of banana pseudo stem and paddy straw in the ratio of $1: 1$ increased the yield ( $14.90 \%$ B.E) which was $34.23 \%$ higher than paddy straw. Hand threshed straw of local indigenous variety showed maximum yield and Biological Efficiency (14.15\%) in comparison to cattle and tractor threshed high yielding rice variety. A range of $10.36 \%$ to $30.57 \%$ increase in Biological Efficiency was obtained with different supplements. Maximum yield ( $16.45 \%$ B.E.) was recorded from $2 \%$ red gram supplemented substrate followed by $2 \%$ rice bran (14.15\% B.E). The above findings will provide valuable information to the cultivators and help them for generating extra income through paddy straw mushroom cultivation.
\end{abstract}

Keywords Volvariella Volvacea, Biological Efficiency, Paddy Straw, Supplementation

\section{Introduction}

Mushrooms are macro fungi which utilized as food and medicines since ancient times. FAO recognizes mushroom as a proteinaceous food for the poor people in underdeveloped countries. Mushrooms contain good quality protein, unsaturated fatty acids, minerals and vitamins [1]. These are low in fat, carbohydrates, salts and rich source of dietary fiber. In addition to nutritional value, edible mushrooms possess unique characteristics in terms of color, taste, aroma and texture, which make them attractive for human consumption [2].The overall production of mushroom in India during 2010 was 1.13 lakh metric tonnes. The per capita consumption of mushroom in India is about $90 \mathrm{~g}$ which is very less as compared to $1.49 \mathrm{~kg}$ in USA and in China $1.16 \mathrm{~kg}$ [3]. Paddy straw mushroom (Volvariella volvacea) is the sixth most important mushroom cultivated in the world with an annual production of 180800 metric tonnes accounting for $3 \%$ of the total mushroom production. This mushroom can use wide range of cellulosic materials and the $\mathrm{C}: \mathrm{N}$ ratio needed is 40 to 60 , quite high in comparison to other cultivated mushrooms. Eastern India comprises North Eastern region (Arunachal Pradesh, Meghalaya, Manipur, Mizoram, Tripura, Sikkim and Assam), West Bengal, part of Bihar, Jharkhand and Odisha has tremendous potential and scope for paddy straw mushroom cultivation due to the easy availability of basic substrate (paddy straw). The high temperature requirement $26^{\circ} \mathrm{C}$ to $30^{\circ} \mathrm{C}$ for mycelium development and 34 to $37^{\circ} \mathrm{C}$ for fructification [4] relative humidity $70-90 \%$ [5] also make it a good choice for adoption in round the year cultivation of mushrooms. This mushroom can be successfully cultivated on several crop residues like paddy straw cotton waste wheat straw and sugarcane industrial waste. The box method of straw mushroom cultivation [6] has shown great promise in Philippines. However helix and tier type beds was found most suitable in India [7]. A wide range of diverse cellulosic substrates were used by various workers for cultivation of $V$. volvacea $[8,9]$. Hand threshed rigid and tall rice straw was found to be more appropriate than dwarf cattle threshed and flexible straw against $V$. esculenta [10]. Cellulose/lignin ratios in substrates were positively correlated to mycelial growth rates and mushroom yields [11] which can be maintained by proper supplementation of substrates. Slightly greater concentration of nitrogen is necessary for the fruiting body formation than the concentration supporting mycelial growth [12]. Many researcher reported the efficacy of organic amendments viz. 
cotton seed cake, cotton waste, neem cake, soyabean meal, deoiled rice bran, mustard cake, wheat bran, gram dal powder etc. for $V$. volvacea $[13,14]$. In this context, studies have been planned to evaluate the potentiality of various substrates, cultivation methods, supplements etc., for enhancing the Biological Efficiency of Volvariella volvacea.

\section{Materials and Methods}

\section{Isolation and maintenance of pure culture of V.volvacea}

Pure culture of V.volvacea was prepared from fresh fruiting body by tissue culture technique [15]. The pure culture of the fungus was maintained on Potato Dextrose Agar (PDA) slants throughout the period of investigation. Sub-culturing of the fungus was done at an interval of one month and stored at $25 \pm 1^{\circ} \mathrm{C}$. Seven days old pure mycelia cultures of the test fungus were used in preparation of mother spawn.

\section{Preparation of stock culture}

Stock culture was prepared from healthy wheat grains which were soaked in tap water over night and next day it was boiled for about 10-15 minutes. These grains were mixed with gypsum $\left(\mathrm{CaSO}_{4} \cdot 2 \mathrm{H}_{2} \mathrm{O}\right)$ and lime $\left(\mathrm{CaCO}_{3} .7 \mathrm{H}_{2} \mathrm{O}\right)$ at a ratio of 2:1[16]. Then grains were autoclaved at $20 \mathrm{lb}$ psi for $2 \mathrm{~h}$. After overnight cooling the flasks were inoculated aseptically with pure culture and incubated for 7 days at $24^{\circ} \mathrm{C}$ $\left( \pm 2^{\circ} \mathrm{C}\right)$.

\section{Spawn preparation}

Healthy wheat grains were boiled, drained off extra water, cooled and gypsum and lime were mixed in the same way. The grains were then filled into $12 \times 18 \mathrm{~cm}$ clear polypropylene bags. To prepare the spawn the quantity of wheat grains per bag was fixed $150 \mathrm{~g}$ which was autoclaved at $15 \mathrm{lb}$ psi for $2 \mathrm{hr}$ at $121^{\circ} \mathrm{C}$. After sterilization, the bags were inoculated with pure cultures of $V$. volvacea and kept in a dark place at $22^{\circ}-24^{\circ} \mathrm{C}$ for 2 weeks for completing the growth of mycelium. Fresh spawns were prepared separately for each experiment.

\section{Preparation of substrate for cultivation}

One year old fresh paddy straw free from any noticeable contaminants was used as substrate for cultivation. Paddy straw bundles of more or less equal in size were selected for the study and the uneven ends of bundles were cut with the help of chaff cutter. The substrate was used directly without any composting or pasteurization. The straw was treated chemically by dipping the substrate into a solution containing $125 \mathrm{ml}$ of formalin and $7.5 \mathrm{~g}$ Bavistin (carbendazim) in 100 liters of water for 12 hours [17]. The wet bundles were removed from the solution and kept inclined for 4 to 6 hours to drain off excess water.

\section{Evaluation of substrates for Paddy Straw Mushroom cultivation}

Paddy straw and it's different combinations with other substrates i.e. Paddy straw + Wheat straw (1:1), + Paddy straw + Banana pseudo stem (1:1), Paddy straw +Water hyacinth (1:1), Paddy straw + Mustard straw (1:1) and Paddy straw + Maize straw (1:1) were tested for their suitability in cultivation of $V$. volvacea. The substrates were dried and washed thoroughly to eliminate the soils and other unwanted materials before soaking in solution for treatment. To prepare the bundles of substrates combinations, all other substrates were mixed with paddy straw in 1:1 combination.

\section{Evaluation of various method of cultivation}

Different methods of paddy straw mushroom cultivation i.e. bed method, cage method, spiral method and heap method were evaluated to identify a suitable method of cultivation for the locality. Equal quantity of substrate was taken for all method.

\section{Bed Method}

For making the beds, 4 bundles were placed side by side and another four bundles similarly but from the opposite side in such a way that, the open ends of bundles should overlap in the middle forming one layer of eight bundles. In similar way second, third $\&$ fourth layers were made. Intermittent spawning was done @ 2\% (dry weight basis) between first and second, second and third and third and fourth layers leaving margin of $12-15 \mathrm{~cm}$ from edges.

\section{Cage Method}

Well drain soaked straw of ten bundles was placed uniformly in the cage $(1.00 \mathrm{~m} \times 0.50 \mathrm{~m} \times 0.25 \mathrm{~m})$ at the bottom layer and $100 \mathrm{gm}$ grain spawn was placed over and inside the bundles. Again placed the second layer of ten bundles over the first and spawn in the similar fashion and repeat the same till six layers of bundles or till complete filling the cage. Finally, the straw was covered with polythene sheet and tied it with jute string.

\section{Heap Method}

The straw was placed in the zig zag manner. Six layered of straw with a depth of 2 feet was prepared and spawning was done @ $2 \%$ (dry weight basis) between the layers. The entire bed was compacted and watered if needed to maintain the moisture. The beds were covered with polythene sheet.

\section{Spiral Method}

Winding of water soaked bundles around wooden poles and mixing of mushroom spawn @ 2\% on dry weight basis 
was followed. The spawned substrate was then covered with thin polythene sheet.

\section{Evaluation of organic supplementation}

Various organic amendments i.e. rice bran, rice flour, wheat bran, wheat flour, red gram powder and mustard cakes were mixed at the rate of $2 \%$ (dry weight basis) to the substrates during cultivation. All the amendments were sterilized in autoclave at $121{ }^{\circ} \mathrm{C}$ and $15 \mathrm{lbs}$ pressure for 10 minutes. The supplements were spread over the spawn between the layers of substrate during spawning for enhancing the mycelium growth.

\section{Effect of substrate quality and of processing method on mushroom productivity}

Straws of different types of rice cultivars i.e. indigenous variety, improved variety and high yielding varieties obtained through hand and cattle thrashing were evaluated for their mushroom yielding ability. Equal size of bundles of cattle thrashed straws was prepared before spawning.

\section{Harvesting of Mushroom}

Paddy straw mushroom usually takes 9-10 days from spawning to first harvest of crop and the first flush normally lasts for 3 days, which constitutes about 70 to $90 \%$ of the expected mushroom yield. The straw mushroom was harvested before the volva breaks or just after rupture. However, full grown mushrooms were also taken into consideration for calculating the biological efficiency.

The biological efficiency was calculated by the following formula,

$$
\text { Bio } \log \text { ical efficiency }(\%)=\frac{\text { Fresh weight of mushroom }}{\text { Weight of dry substrate }} \times 100
$$

\section{Statistical Analysis}

Completely Randomize Design was followed in experiments. A unit of $10 \mathrm{~kg}$ dry substrate was taken for each replication and three replications were maintained for each set of treatment. The experimental data were statistically analyzed. The critical differences were worked out at $5 \%$ probability level.

\section{Results}

\section{Effects of method of cultivation}

To identify a suitable cultivation technique for paddy straw mushroom under the agro-ecological condition of Eastern India, four methods i.e, bed method, cage method, spiral method and heap method were evaluated and the data have been presented in table -1 .

Methods tested for cultivation of paddy straw mushroom showed different response in terms of biological efficiency and other parameters. Cage method of cultivation was proved its superiority among all the methods tested and gave highest yield and biological efficiency (1210 g and $12.10 \%$ ) followed by bed method and spiral method of cultivation which exhibited (1140 $\mathrm{g}$ and $11.40 \%)$ and (1020 g \& $10.20 \%)$ respectively. Heap method of cultivation was found to be less suitable under the agro-climatic condition.

The spawn run period was minimum (8.66) days in cage method of cultivation followed by bed method ( 9 days) and spiral method of (10 days). Maximum time (11.33 days) was taken by the heap method of cultivation. The effect of various methods of cultivation on the average number and weight of sporophore was also recorded. Maximum average weight of sporophore $(26.89 \mathrm{~g})$ was observed from cage method of cultivation, which was significantly superior amongst all the methods evaluated followed by bed method $(21.11 \mathrm{~g})$ and spiral method of cultivation $(19.25 \mathrm{~g})$.

\section{Effect of different substrates}

To increase the biological efficiency of $V$. volvacea, various combinations of substrates were tested along with paddy straw. The data obtained on various parameters have been presented in table-2.

The yield of $V$. volvacea was found to be influenced greatly by the substrate combinations. Maximum yield and biological efficiency (1490 g \& $14.90 \%$ ) was obtained from banana pseudo stem + paddy straw 1:1 substrate which differ significantly from other treatments. Water hyacinth +paddy straw $1: 1$ responded fairly and produce $8.56 \%$ higher yield than control (paddy straw). Minimum yield and biological efficiency of mushroom (708 g \& $7.08 \%$ ) was observed from mustard straw + paddy straw 1:1 substrate. Wheat straw + paddy straw (1:1) substrate took minimum time ( 8.67 days) for completing the spawn run and produced mushroom earlier than paddy straw ( 9 days ). The substrate banana pseudo stem + paddy straw (1:1), though produced maximum yield took 10.33 days for spawn run. The differences in spawn run period of various substrates were found to be non-significant.

\section{Effect of straw quality on mushroom productivity}

Six different qualities of paddy straw were used to find out the appropriate quality of straw for obtaining higher B.E. of paddy straw mushroom. Observations were taken on different parameters are presented in Table-3.

It was evident from the Table-3 that the yield of mushroom varied considerably with the substrate quality. Maximum yield (1487.50 g) was recorded from the substrate prepared from hand threshed indigenous variety $(14.87 \%$ B.E.). However, the cattle threshed straws were found inferior $(6.90-8.13 \%$ B.E.) in respect of yields reflecting their unsuitability for the purpose. Hand threshed straws were also found to be more suitable for faster development of mycelium which resulted in shorter spawn run period (8.50-9.28 days). Sporophores number of was highest (77.25) in case of hand threshed straw of local indigenous varieties. 
Table 1. Evaluation of different methods of cultivation for higher biological efficiency

\begin{tabular}{|c|c|c|c|c|c|c|}
\hline Sl.No & Cultivation method & $\begin{array}{l}\text { Total yield } \\
(\mathrm{g})\end{array}$ & B.E. \% & $\begin{array}{l}\text { Avg.. no. of } \\
\text { sporophores }\end{array}$ & $\begin{array}{l}\text { Avg.weight of } \\
\text { sporophore( } g)\end{array}$ & $\begin{array}{c}\text { Spawn run } \\
\text { period(days ) }\end{array}$ \\
\hline 1 & Bed method & 1140 & $\begin{array}{c}11.40 \\
(2.432)\end{array}$ & $\begin{array}{c}549 \\
(7.346)\end{array}$ & 21.11 & $\begin{array}{c}9.00 \\
(3.10)\end{array}$ \\
\hline 2 & Cage method & 1210 & $\begin{array}{c}12.10 \\
(2.492)\end{array}$ & $\begin{array}{c}45 \\
(6.706)\end{array}$ & 26.89 & $8.66(2.939)$ \\
\hline 3 & spiral method & 1020 & $\begin{array}{c}10.20 \\
(2.321)\end{array}$ & $\begin{array}{c}53 \\
(7.277)\end{array}$ & 19.25 & $10.00(3.159)$ \\
\hline 4 & Heap method & 880 & $\begin{array}{c}8.80 \\
(2.174)\end{array}$ & $\begin{array}{c}69 \\
(8.306)\end{array}$ & 12.75 & $11.33(3.365)$ \\
\hline & $\begin{array}{c}(+) \text { SE } \\
\text { C.D }(0.05)\end{array}$ & 0.283 & 0.924 & $\begin{array}{l}0.111 \\
0.492\end{array}$ & $\begin{array}{l}0.441 \\
1.438\end{array}$ & $\begin{array}{l}0.807 \\
0.263\end{array}$ \\
\hline
\end{tabular}

Data in parenthesis are transformed value

Table 2. Evaluation of substrates for higher biological efficiency of Paddy Straw Mushroom

\begin{tabular}{|c|c|c|c|c|c|c|c|c|}
\hline Sl No. & Substrates & $\begin{array}{c}\text { Total } \\
\text { yield }(\mathrm{g})\end{array}$ & B.E. \% & $\begin{array}{l}\text { Avg.no. of } \\
\text { sporo- } \\
\text { phores }\end{array}$ & $\begin{array}{l}\text { Avg. weight } \\
\text { of sporo- } \\
\text { phore (g) }\end{array}$ & $\begin{array}{c}\text { Spawn run } \\
\text { period } \\
\text { (days }\end{array}$ & $\begin{array}{l}\% \text { over } \\
\text { control }\end{array}$ & Remarks \\
\hline 1 & $\begin{array}{c}\text { Maize straw + Paddy } \\
\text { straw } 1: 1\end{array}$ & 881.67 & $\begin{array}{c}8.82 \\
(2.165)\end{array}$ & $\begin{array}{c}42 \\
(6.467)\end{array}$ & 20.99 & $\begin{array}{c}9.33 \\
(3.054)\end{array}$ & -20.57 & $\mathrm{IN}, \mathrm{CMA}$ \\
\hline 2 & $\begin{array}{c}\text { Banana pseudo stem }+ \\
\text { Paddy straw } 1: 1\end{array}$ & 1490 & $\begin{array}{l}14.90 \\
(2.147)\end{array}$ & $\begin{array}{c}48 \\
(7.272)\end{array}$ & 31.04 & $\begin{array}{c}10.33 \\
(3.208)\end{array}$ & +34.23 & \\
\hline 3 & $\begin{array}{l}\text { Water hyacinth } \\
+ \text { +Paddy straw 1:1 }\end{array}$ & 1205.00 & $\begin{array}{l}12.05 \\
(2.482)\end{array}$ & $\begin{array}{c}42 \\
(6.457)\end{array}$ & 28.69 & $\begin{array}{l}10.67 \\
(3.260)\end{array}$ & +8.56 & \\
\hline 4 & $\begin{array}{c}\text { Wheat straw + Paddy } \\
\text { straw } 1: 1\end{array}$ & 1045.00 & $\begin{array}{l}10.45 \\
(2.344)\end{array}$ & $\begin{array}{c}62 \\
(7.861)\end{array}$ & 16.85 & $\begin{array}{c}8.67 \\
(2.942)\end{array}$ & -5.86 & \\
\hline 5 & $\begin{array}{c}\text { Mustard straw + Paddy } \\
\text { straw } 1: 1\end{array}$ & 708.33 & $\begin{array}{l}7.08 \\
(1.953)\end{array}$ & $\begin{array}{c}71 \\
(8.424)\end{array}$ & 9.98 & $\begin{array}{l}11.67 \\
(3.406)\end{array}$ & -36.19 & IN,CMA \\
\hline \multirow[t]{3}{*}{6} & Paddy Straw(Control) & 1110.00 & $\begin{array}{c}11.1 \\
2.402)\end{array}$ & $\begin{array}{c}47 \\
(6.842) \\
\end{array}$ & 23.62 & $\begin{array}{c}9.00 \\
(2.996) \\
\end{array}$ & 0 & \\
\hline & (土) $S E$ & 67.701 & 0.700 & 0.287 & 1.134 & 0.117 & & \\
\hline & $C . D(0.05)$ & 208.627 & 0.215 & 0.884 & 3.495 & 0.36 & & \\
\hline
\end{tabular}

Data in parenthesis are transformed value

IN- Insect infestation, CMA- Competitor Mould Attack

Table 3. Effect of Straw Quality on Mushroom Productivity

\begin{tabular}{|c|c|c|c|c|c|c|}
\hline $\begin{array}{l}\text { Serial } \\
\text { No. }\end{array}$ & Treatment & $\begin{array}{l}\text { Total yield } \\
(\mathrm{g})\end{array}$ & B.E. \% & $\begin{array}{c}\begin{array}{c}\text { Avg.no. } \\
\text { of } \\
\text { sporoph-ores }\end{array} \\
\end{array}$ & $\begin{array}{l}\text { Avg. weight of } \\
\text { sporop-hore } \\
(\mathrm{g})\end{array}$ & $\begin{array}{c}\text { Spawn run } \\
\text { period } \\
\text { (days }\end{array}$ \\
\hline 1 & $\begin{array}{l}\text { Hand threshed indigenous } \\
\text { variety }\end{array}$ & 1487.50 & 14.87 & 77.25 & 18.75 & 8.50 \\
\hline 2 & $\begin{array}{l}\text { Hand threshed Improved } \\
\text { variety }\end{array}$ & 1215.00 & 12.15 & 63.00 & 18.80 & 9.25 \\
\hline 3 & Hand threshed HYV & 1033.75 & 10.33 & 55.00 & 18.75 & 8.75 \\
\hline 4 & $\begin{array}{c}\text { Cattle threshed indigenous } \\
\text { variety }\end{array}$ & 813.75 & 8.13 & 43.50 & 18.38 & 11.25 \\
\hline 5 & $\begin{array}{l}\text { Cattle threshed Improved } \\
\text { variety }\end{array}$ & 690.00 & 6.90 & 38.50 & 17.00 & 12.25 \\
\hline \multirow[t]{3}{*}{6} & Cattle threshed HYV & 790.00 & 7.90 & 43.75 & 17.75 & 12.75 \\
\hline & $( \pm) S E$ & 29.857 & 0.248 & 2.351 & 2.334 & 0.290 \\
\hline & C. $\bar{D}(0.05)$ & 91.962 & 0.745 & 7.244 & 7.241 & 0.895 \\
\hline
\end{tabular}

\section{Effect of organic supplementation on mushroom productivity}

The effects of various organic amendments on the yield and biological efficiency of paddy straw mushroom are presented in table-4. 
Table 4. Effect of organic supplementation on biological efficiency of Paddy Straw Mushroom

\begin{tabular}{|c|c|c|c|c|c|c|c|c|}
\hline Sl No. & Supplements & $\begin{array}{c}\text { Total } \\
\text { yield } \\
(\mathrm{g})\end{array}$ & $\begin{array}{c}\text { B.E. } \\
\%\end{array}$ & $\begin{array}{l}\text { Avg.no. of } \\
\text { sporo-phores }\end{array}$ & $\begin{array}{l}\text { Avg. weight } \\
\text { of sporo- } \\
\text { phore } \\
(\mathrm{g})\end{array}$ & $\begin{array}{c}\text { Spawn run } \\
\text { period } \\
\text { (days }\end{array}$ & $\begin{array}{c}\% \\
\text { over control }\end{array}$ & Remarks \\
\hline 1 & Rice bran@2\%, & 1415.00 & 14.15 & 71 & 19.93 & 9.333 & 20.43 & \\
\hline 2 & Rice flour@2\% & 1530.00 & 15.30 & 75 & 20.4 & 9.666 & 30.21 & \\
\hline 3 & Wheat bran@2\% & 1220.00 & 12.20 & 64 & 19.06 & 9.000 & 3.83 & \\
\hline 4 & Wheat floor @2\% & 1310.00 & 13.10 & 69 & 18.99 & 9.333 & 11.49 & \\
\hline 5 & Red gram powder@2\% & 1645.00 & 16.45 & 73 & 22.53 & 8.333 & 40.00 & \\
\hline 6 & Mustard cake @2\% & 1025.00 & 10.25 & 75 & 13.67 & 11.000 & -12.77 & IN,CMA \\
\hline \multirow[t]{3}{*}{7} & Paddy straw(Control) & 1175.00 & 11.75 & 65 & 18.08 & 9.000 & 0.00 & \\
\hline & (土) $S E$ & 27.922 & 0.195 & 0.119 & 2.00 & 0.814 & & \\
\hline & $C D$ at $5 \%$ & 84.684 & 0.592 & 0.362 & 6.065 & 0.247 & & \\
\hline
\end{tabular}

IN- Insect infestation, CMA- Competitor Mould Attack

Majority of the supplements i.e. rice bran, rice flour, wheat bran, wheat flour, red gram powder were contributed positively towards the yield of $V$. volvacea. While, mustard cake contributed negatively and gave lesser yield than control. Highest yield and biological efficiency (1645 $\mathrm{g}$ and $16.45 \%$ ) were obtained from the substrate supplemented with $2 \%$ red gram powder which was $40 \%$ higher than control followed by rice flour (1530 $\mathrm{g} \& .15 .30 \%)$, rice bran (1415 g \& $14.15 \%)$, wheat flour (1310 g \& $13.10 \%)$ and wheat bran $(1220 \mathrm{~g} \& 12.20 \%)$ supplemented substrates. Significant differences were observed among the treatments over control. A range of 3.83 to $30.21 \%$ increase in yield was noticed from other supplemented substrates than paddy straw.

\section{Discussion}

Cage method of cultivation has an extra advantage over the other methods as it maintains proper temperature and aeration inside the bed due to proper shape and size, which enable the mushroom mycelium to grow faster than the others. The above mentioned fact could be one of the reasons of higher biological efficiency of paddy straw mushroom in cage method of cultivation. Similar results with cage method of cultivation were also reported by [18]. However, the results obtained from bed method of cultivation over the spiral method were not corroborated with the reports [19].

Volvariella volvacea depends largely on the cellulose and hemicellulose of the substrates, their total nitrogen and carbon contents and $\mathrm{C}$ : $\mathrm{N}$ ratio. Presence of more cellulose content and higher $\mathrm{C}: \mathrm{N}$ ratio in banana pseudo stem and water hyacinth in comparison to paddy straw could be one of the reasons for higher yield and biological efficiency of $V$. volvacea. This finding further confirming the reports of [20]. Compactness and high lignin in wheat straw beds may lead to the poor formation of mushroom primordia and hence reduced the yield in wheat straw + paddy straw 1:1 substrate. Similar observations with wheat straw substrate were also made by [21]. Presence of more lignin and volatile components in mustard straw, nematodes and moulds attack in the beds of mustard straw + paddy straw 1:1 substrate could be the reasons for slow spawn run, poor yields and biological efficiency of Volvariella volvacea.

The investigation on the effect of straw quality on mushroom productivity indicated superiority of hand threshed local indigenous tall rigid straw in yielding mushrooms with the biological efficiency of $14.87 \%$. The compactness and flexibility of the cattle threshed straw types possibly restrict movement of air, water and light into the bed necessary for the fungus to grow and primordial formation. Further, the loose straw decomposes fast in hot and humid climate making it unsuitable for straw mushroom cultivation. Tall, hand threshed and rigid straw yielded better than dwarf, cattle threshed and flexible straw [22]. The same finding was confirmed by [23].

The results obtained with $2 \%$ red gram powder were further confirmed the findings of [24]. While, presence of active volatile sulpher compounds may resulted in higher substrate temperature which may injure mushroom spawn, reduced mycelial growth rates, and leave the substrate vulnerable to competitors molds such as Coprinus spp. (ink caps), Trichoderma spp. (green mold), Aspergillus niger, Penicillium sp. Sclerotium sp. in mustard cake supplemented substrate could be the reasons for lower yield and biological efficiency of paddy straw mushroom.

\section{Conclusions}

The eastern region of India has tremendous potential and scope for paddy straw mushroom cultivation due to the easy availability of basic substrate (paddy straw). The high temperature requirement for the cultivation of Volvariella volvacea also makes it a good choice for adoption in round the year cultivation. The present findings provide a good deal of information regarding the increasing of biological efficiency of paddy straw mushroom especially in eastern India, which also help the poor farmers for increasing their profit and income. 


\section{REFERENCES}

[1] Chang S-T, Miles PG. (2004). Mushrooms, Cultivation, nutritional value, medicinal effect, and environmental impact (2nd ed.). CRC Press. pp. 451.

[2] Chang, S. T. and Miles, P. G. (1991). Recent trends in world production of cultivated edible mushrooms. Mush J, 503, pp. $15-18$.

[3] Wakchaure,G.C. (2011). Production and Marketing of Mushrooms: Global and National Scenario. In: Manjit Singh, Bhuvnesh Vijay, Shwet Kamal and G.C. Wakchaure (Ed.), Mushrooms Cultivation, Marketing and Consumption (pp.15-22). Directorate of Mushroom Research, Solan -173213 (HP), (ICAR) Publishing.

[4] Chang, S.T.(1972). The Chinese Mushroom (Volvariella volvacea) - Morphology, Cytology, Genetics, Nutrition and Cultivation, The Chinese University of Hong Kong Press.

[5] Diwakar-Bahukhandi and Bahukhandi, D.1989. Cultural triads on Volvariella volvacea. Indian Phytopathology 42 (3), pp.441-443.

[6] Alicbusan, R.V. and Santiago, C.H. Jr., (1975).“ Mushroom Growing (Volvariella volvacea)," Philippine Biota, 9, 120.

[7] Garcha ,H.S. , and Kalra, K. L. (1978). Paddy straw mushroom in North India. Mushroom Science 10(11), pp.645-52.

[8] Quimio, T. H. (1978) Indoor cultivbation of Pleurotus ostreatus using Philippine agricultural wastes. Philip Agri, 61,pp. 253-262.

[9] Fang ,A.J. (1989). High yield utilization of Volvariella volvacea in the open. Edible Fungi in China 3, 31.

[10] Krishnamohan, G. (1975). Studies on paddy straw mushroom (V. esculenta) (Massee) Sing. M.Sc.thesis, Tamil Nadu Agric. Univ. Coimbatore, p.171.

[11] Philippoussis, A.; Zervakis, G. and Diamantopoulou,P.(2001) Bioconversion of agricultural lignocellulosic wastes through the cultivation of the edible mushrooms Agrocybe aegerita, Volvariella volvacea and Pleurotus spp. World Journal of Microbiology and Biotechnology, 17(2),pp.191-200.

[12] Chang, S.T.(1978).The Biology and cultivation of edible
mushrooms.Academic Press,New York . 819p

[13] Gupta, G.K., Bajaj, B.S. and Suryanarayan, D.(1970). Studies on the cultivation of paddy straw mushroom Volvariella volvacea and V. diplasia, Indian Phytopath. 23, pp.615-620.

[14] Patra, A.K. and Narain, A. (1997). Studies on the productivity of locally available edible mushroom (Volvariella and Calocybe) with respect to their commercial cultivation. Ph.D. Thesis, Department of Plant Pathology, Orissa University of Agriculture and Technology, Bhubaneswar, India.

[15] Jonathan, S. G., Bawo, D. D. S., Adejoye, D. O., Briyai, O. F., 2009. Studies on biomass production in Auricularia polytricha collected from Willberforce Iseland, Bayelsa State, Nigeria. American Journal of Applied Science 6 (1), pp. 182-186.

[16] Jandaik, C. and Kapoor, J. (1976). Studies on the cultivation of Pleurotus sajorcaju. Mush Sci, 9(1),pp. 667-672.

[17] Vijay, B. and Sohi, H. S. (1987). Effect of different sterilants and farm wastes on yield of Pleurotus citrinopileatus. Mush J Tropics, 7, pp. 67-75.

[18] Samajpati, N. (1979). Nutritive value of some Indian edible mushrooms,Mushroom Sci.,10(2),pp. 695-703.

[19] Thakur, M.P. and Yadav, V. (2006). Modern technique of cultivation of paddy straw mushroom in a commercial scale. In. Emerging area of Mushroom Diversity, Production and Post Harvest Developments.(Eds.), Department of Plant Pathology, Indira Gandhi Agricultural University, Raipur, India. pp.10-25.

[20] Saeed ,M., Khan , S. M. and Inam UL Haq, M. (1994). Cultivation of Chinese mushroom Volvariella volvacea on the water hyacinth (Eichornia crassipes). Pakistan Journal of Phytopathology 6(2), pp. 130-134.

[21] Garcha ,H.S., and Kalra, K. L. (1978). Paddy straw mushroom in North India. Mushroom Science 10(1), pp. 645-52.

[22] Krishnamurty, C. S., LalithaKumari and Shanmungam, N.(1968). A simple technique for increasing the yield of straw mushroom. Volvariella diplasia (Berk and Br.).Sacc. Madras Agric., J. 55,pp. 194-195.

[23] Munjal, R.L. (1975). Production of paddy straw mushroom. Indian Journal of Mushroom 2, pp. 32-38.

[24] Ramasamy,K and Kandaswamy, T.K. (1975).Effect of spawn media on spawn quality and yield of Volvariella volvacea. Massee. 16th Ann. Microbiol. Conf. Assoc. Microbiologists India, Rishikesh, p.76(Abstract). 